these relics are pre-glacial. The most one can say about them is simply this, that the folk who used them lived in England before the climax of glacial cold. When human relics are got in beds of older date than those at Cromer, we shall then have a demonstration of the pre-glacial age of man in Britain. At the same time the presumption is (as many geologists will admit) that some portion of our ancient river-drifts and cave-deposits with flint implements do really belong to pre-glacial times. In short, afrer carefully reading the proceedings at the recent Conference, I find nothing to shake me in my present belief that none of the palæolithic deposits belongs to post-glacial times, but that all must be relegated to inter-glacial, and probably pre-glacial ages, and consequently that the palæolithic is separated from the neolithic age by the intervention of the last cold period of the glacial epoch. My opinion, therefore, is still as strong as ever that "until we clearly understand what was the succession of changes during the ice age, it is premature to speculate upon the geological age of those deposits which yield the earliest traces of man in Britain." In concluding, may I be allowed to suggest to the anonymous writer whose communication on the subject of the Antiquity of $M a n$ appears in the number of this journal for June 7 , that before he again essays to criticise my views he might do well to become better acquainted with them. JAMEs GEIKIE

Perth, June 15

BEFORF your readers accept the statements of Messrs. Evvans and Hughes respecting my discovery of flint tools beneath the great chalky boulder-clay, as announced in NATURE last year, may I ask them to remember that as yet I have not published the evidence upon which I founded my statement? The delay has arisen from official and other causes; and although my paper is now written, it is, I have just learned, too late for reading during the present session at the Geological Society. Neither of the two gentlemen named is aware of the extent of my evidence, for $T$ have not, as yet, told any one about it, except the two geolists mentioned below. As I shall show, there are now hnown to me about forty localities in which the brick-earths in question occur, and in most of them their relation to the boulder-clay is very clear; and even in the two or three spots in which that rock is not seen in the actual section, it overlies the implement beds near by on the same outcrop. The brick-earths have natu. rally suffered much denudation by the boulder-clay, and I have a splendid series of sections showing every phase from almost undisturbed material beneath the boulder-clay to small fragments (boulders, in fact) in that deposit. I wish, also, to state, that instead of four implements from two localities, as originally announced, I know at present nearly I 50 from six different spots. The evidence is so clear and overwhelming when seen en masse, that it must be convincing to all who carefully weigh it. The boulder-clay which overlies the brick-earths in question is part and parcel of the great mass of the chalky boulder-clay, a formation which I have spent eight years in examining in the field almost daily, of which I have mapped about 2,000 square miles, and upon which I feel quite competent to form an opinion.

Prof. Prestwich is perfectly correct in ascribing the wellknown palæolithic implements found in the gravel to a time suibsequent to the formation of the chalky boulder-clay; but that only proves those tools to be newer than the last glaciation of this particular area. Now inasmuch as Mr. Searles V. Wood, jun., long ago proved, and as everybody who examines the ground must admit, that the "purple" and "hessle" boulder-clays are newer than the one we are dealing with, and as Dr. J. Geikie has shown that gravels bearing the same character and possessing the same peculiar fauna as the well-known palæolithic gravels (overlying, moreover, the chalky boulder-clay), pass under these newer beds, it is, to say the least, a misnomer to call these gravels post-glacial. They are post-glacial to this East Anglian area, but not to northern England; and the distribution of surfacebeds containing palæolithic implements throughout Europe shows that they are confined exclusively to that area which was free from the erosive action of the newer and less intense icesheets of the latter part of the "Great Ice Age." Much of the misapprehension in this matter has arisen from the unfortunate name of "upper" given to the chalky boulder-clay. It is "upper" in East Anglia, but it is "lower" in Yorkshire.

My discovery does not prove man to have been pre-glacial; it merely shows that he was "pre-chalky-boulder-clay," and I last week obtained evidence to show that the brick.earths in question belong to the "middle glacial" of Mr. Searles V. Wood, jun. ; that is to say, they are newer than the Cromer till, but older than the chalky boulder-clay.
Mr. Belt is mistaken respecting the quartzite implements near Brandon. They are found in gravel which is unquestionably above the boulder-clay, as can be seen in hundreds of sections, and the only conceivable source of that material is the bonklerclay. We have, in fact, two horizons of palrolithic implements, one above and one below the boulder-clay, and I am in hopes that the former will be found capable of subdivision, for many facts crop up in the course of my daily work which seem to point in that direction.

Prof. Ramsay and Dr. J. Geikie, who are eminently capable of judying of glacial phenomena, have gone over the area with me, and are perfectly convinced of the accuracy of my determinations.

Brandon SYJNEY B.J. SKERTCHLY

\section{Nicephore Niepce}

THERE is an error in one of your "Notes" of last week which you may be glad to have corrected. It is not to Niepce de St. Victor that the citizens of Chalons-sur- Saône ( $a$ town, by the way, not to be mistaken for Chalons in the Champanne country) are about to eiect a statue, but to his uncle, Joseph Nicephore Niepce, who might well be designated as the first photographer, since he it was who succeeded first of all in fixing an image in the camera. In a "Life of Nicephore Niepce," recently published by Victor Fouqué, appear letters which leave little doubt that in May, I8I 6 Niepce had accumplished the feat of fixing shadows in the camera, for in a communication of that date to his brother he incloses four photographs, of which he says: "The pigeon-house is reversed on the pictures, the barn, or rather the roof of the bain, being to the left, instead of the right. The white mass which you perceive to the right of the pigeon-house, and which appears somewhat confused, is the reflection upon the paper of the pear-tree, and the black spot near the summit is an opening between the branches of the trees. The shadow on the riglat inclicates the roof of the bakchouse." This, then, is a description of the first camera-picture ever taken, and it was by reason of Niepce's inability to prevont his impressions from fading afier a lapse of time that he cumed his attention to the bitumen of Judea process, with which he produced photographs as eariy as 1824 , one or two specimens being still among the science treasures of the British Museum.

The name of Nicephore Niepce is little known in Lngland, And yet this should not be. As is well known he came to this country in I827, and resided at Kew in the hope to receive aid and encouragement, and shortly afterwards, on his return to France, entered into partnership with Damerre to work out together a more practical process. When Uaguerre made known his discovery in I839, his partner had been dead two years, and no mention was made of Niepce at the time Arago made his famous speech announcing the discovery of Daguerreotype. Specimens of the wonderful process were not lons in reaching this country and the first picture was placed in Faraday's hands with the remark that he had never seen anjthing like it before. But Faraday said he had. A Frenchman, he remembered, had brought him a picture of Kew Church a dozen years ago, with the quaint remark, that "the sun had done it." Faraday was so certain of this that inquiries were at once instituted into the matter, and in the end, a communication was addressed by the Secretary of the Royal Society, Mr. Bauer, to the Academie at Paris, a communication which helped materially to substantiate the claim of the Niepce family, and to obtain for the son Isidore, a pension in acknowledgment of the father's services. The deed of partnership between Niepce and Daguerre is still extant, but how much of the latter's pub. lished results were due to his dead partner the world will never know.

June 16 H. BADEN PRITChard

\section{Japanese Mirrors}

THERE is still something to be solved about the Japanese mirrors, which show the figures that appear in relief on the back in the disk of light reflected from the face. Not only does it seem impossible (without some indication which I have not yet met with) to tell which mirrors in a series will perform the feat but it is equally difficult to say why one bunch of leaves will, and another in the same casting, will not appear in the spectrum.

In reference to Mr. Highley's quotation of Mr. Prinseps' conjecture (p. I32), "that the thinnest parts, from being the hardest, " "La Vexité sur l'Invention de la Photographie." 